\title{
Assessment of Bargaining Power in Preparation of International Business Negotiations Strategies: Case of Wholesale Trade
}

\author{
Kęstutis Peleckis ${ }^{1, a^{*}}$ \\ ${ }^{1}$ Doctoral student, Faculty of business management, Vilnius Gediminas Technical University, \\ Lithuania \\ a* Corresponding Author: k.peleckis@vgtu.It
}

\begin{abstract}
Keywords: negotiation, bargaining power, wholesale trade, bargaining power assessment, strategic decisions, negotiations support.
\end{abstract}

\begin{abstract}
Recently businesses need to find the new ways to ensure business growth and competitiveness in the international market. Cultural diversity of international business brings new challenges in the development and implementation of negotiation strategies of businesses, in cooperation with foreign partners. At present business solutions are used for development and implementation of negotiating strategies for international business, which are not universally suitable for business development in all situations in context of globalization, with current challenges, which are characterized by increasing risk, uncertainty and cultural differences. New challenges in international business negotiations are caused by formation of common cultural and information space in a global scale, the new demands for information technology progress in development of international competition and accelerating innovation processes. International business negotiation strategy development and implementation are setting the essential features and causal relations and is relevant in practice by creating in each negotiation case the unique negotiation strategy, focused on maximizing the effectiveness of the international business with the aim of more efficient use of business negotiation potential - the negotiating power. In scientific problem solving it is necessary to offer such instruments, which would take into account bargaining power of participants in negotiations, and would allow real implementation of business strategies and constitute an appropriate contribution to their development. The article aims - to design a theoretical model for preparing and implementing strategies of international business negotiations, based on evaluations of bargaining powers and to verify experimentally its relevance and applicability.
\end{abstract}

\section{INTRODUCTION}

The modern business world faces with a huge multicultural diversity and its inherent specificity, requiring adequate theoretical solutions in the organization and management of international business. International business development under conditions of globalization determines that representatives of many different cultures are participating in different negotiations. This leads to additional difficulties in modeling the negotiating strategic decisions and ensuring their support. Therefore, there is an obvious need to develop adequate models of real bargaining situations, assessing the potential of the negotiating parties - their bargaining power. In this article is checked authors created model, which is designed to help in developing strategies of international business negotiations, based on the assessment of bargaining power. This model will be tested in a typical area of international business negotiations - in wholesale trade. The model is based on the game theory methods in order to find the optimal strategy of negotiations, to customize the optimization rules for international trade negotiations under uncertainty. The created model is designed for the development and implementation of strategies based on the assessment of bargaining power, for the analysis of the strategic actions in the negotiations and strategic decision-making. The complexity and systematic of negotiating issues determines the need to take into account the abundance of criteria for assessing the situations, processes and negotiating potential. For this purpose we use multi-criteria analysis by using experts. The results indicate that created model can be used to 
support international business and e-business negotiations as an independent systematic element of negotiating process (standalone or in part, requiring intervention by the negotiator).

Problem. There are no theoretical solutions in theory of management, as well as in business management for the assessment of bargaining power in international business negotiations, with regard to particularly relevant options to use in the negotiating process their support technologies.

Research object. To support drafting of international business negotiation strategies based on bargaining power evaluations.

The research aim. To present a theoretical model for the development and implementation of strategies in international business negotiations, based on the assessment of bargaining power, and verify experimentally its adequacy and applicability in the wholesale trade.

Research methods - comparative, logical analysis and synthesis of scientific literature, comparison and generalization methods, mathematical and statistical methods of data analysis.

\section{Model for Developing Strategy of International Business Negotiations Based on Evaluations of the Bargaining Power}

In our opinion the development and implementation of negotiation strategies must rely on evaluation of bargaining power. As knowledge of negotiation situations may take place during the negotiating process the strategy and tactics of actions (steps) can vary with each new issue. The analysis of scientific literature (Ginevičius et al. 2013; Ginevičius 2008; Tamošiūnas 2011; Zavadskas et al. 2015; Zavadskas 2004) shows that the application of heuristic algorithms in creation model for development and implementation the negotiating strategy in order to assess the bargaining power and to reflect better the progress of negotiations is promising. We define the condition that each negotiating issue will be considered only once, without returning to it. The heuristic algorithm will seek to find wins strategies, generating the greatest aggregate benefits in negotiations. For this purpose will be used optimization rules, proposed by various scientists (Hurwitz, Wald, Savage and Niehaus, Bernoulli-Laplace, Bayes-Laplace, Hodges and Lehmann). We provide rankings of negotiation issues so that matters will go from the most important to least important, in order to ensure that the further course of negotiations would not be in vain. For example, finding out in the final stage of negotiations, that the other side can't meet the basic criteria (the negotiating team has not the person empowered to sign the agreement or contract), it turns out that all the costs of the negotiations have been made in vain.

This optimization task is quite complicated because of the single most useful wins of the previous negotiation issues do not necessarily will provide the most useful amount of total winnings of all the negotiating issues, which implies that you must look for the best value of total wins in negotiations - to solve the task of global optimization. For example: in negotiations are settled three issues in each of them solution is selected from available alternatives. Although the wins from the first two questions were not the most useful but their choice has led to wins from the best third questions alternative, which brings the maximum possible benefit of the whole negotiation process.

After defining the priority list of negotiating issues, we must emphasize that on each issue is negotiating with a set of potential negotiating partners. Assume that negotiator has a finite set of alternatives and each issue consists of $t$ alternatives. Let us denote alternatives $b_{i, j}, j=$ $1,2,3, \ldots, t_{i}$ for the $i$-th question. Then the $i$-th question of all alternatives set of values is denoted $\mathrm{w}_{\mathrm{i}}=\left\{\mathrm{b}_{\mathrm{i}, 1}, \mathrm{~b}_{\mathrm{i}, 2}, \ldots, \mathrm{b}_{\mathrm{i}, \mathrm{t}_{\mathrm{i}}}\right.$, and $\mathrm{w}_{1} \times \mathrm{w}_{2} \times \mathrm{w}_{3} \ldots \mathrm{w}_{\mathrm{n}}$ is the set of all possible negotiation scenarios when for every issue is selected one from the available alternatives, $\mathrm{n}$ is the number of negotiating issues.

Noted $b_{0}$ as start of negotiations, the whole negotiation process can be shown in a graphic-tree (Fig. 1), where the arcs $\mathrm{H}_{\mathrm{i}, \mathrm{b}_{\mathrm{ij}}}$ denotes winnings after we have chosen the $\mathrm{j}$-th alternative to resolving the the $\mathrm{i}$-th issue.

$$
\max _{k \in w_{1} \times w_{2} \times w_{3} \ldots w_{n}}\left(\sum_{i=1}^{n} H_{i, b_{i, j}}\right), j=1, \ldots,\left|w_{i}\right|
$$


there:

$\mathrm{H}$ - the negotiators issue as winnings according to the chosen optimization rule (Hurwitz, Wald, Werner etc.);

$\mathrm{n}$ - the number of negotiating issues (peaks mark the start and end of negotiations).

The peak $b_{0}$ marks the start of negotiations, peaks bij notes the $j$-th alternative of $i$-th question, and the arcs $\mathrm{H}_{\mathrm{i}, \mathrm{b}_{\mathrm{ij}}}$ indicates winnings, which we could have by selecting $\mathrm{j}$-th alternative in solving the $i$-th issue $j \in w_{1} \times w_{2} \times w_{3} \ldots w_{n}$.

Further, as an example, we shall provide Hurwitz formula, which will be used in order to find the best issue winnings for negotiations at the uncertainties:

Where:

$$
\begin{aligned}
& \mathrm{H}_{\mathrm{u}}=\max _{\mathrm{u}}\left[\gamma \min _{\mathrm{z}} \mathrm{a}_{\mathrm{uz}}+(1-\gamma) \max _{\mathrm{z}} \mathrm{a}_{\mathrm{uz}}\right] \text { (the best maximal decision); } \\
& \mathrm{H}_{\mathrm{u}}=\min _{\mathrm{u}}\left[\gamma \max _{\mathrm{z}} \mathrm{a}_{\mathrm{uz}}+(1-\gamma) \min _{\mathrm{z}} \mathrm{a}_{\mathrm{uz}}\right] \text { (the best minimal decision). }
\end{aligned}
$$

$\mathrm{H}$ - negotiator winnings on negotiating issue by Hurwitz rule.

$\mathrm{a}_{\mathrm{uz}}-$ negotiator winnings, which he is able to get if he will do the move $\mathrm{u}$ in case if opponent will make a move $\mathrm{z}$.

Negotiators set of moves is finite and consist of the moves which will be numbered: $u=1,2$, $3, \ldots, \mathrm{S}$.

We accept the assumption that opponent's set of possible moves is finite and consists of k moves which are numbered: $\mathrm{z}=1,2,3, \ldots, \mathrm{k}$.

$\gamma$ - hope parameter; $\gamma$ - a factor that varies from 0 to 1 . In the formula we can see that if $\gamma=1$ so Hurvico criteria coincide with Waldo, this is with the pessimistic criterion.

If $\gamma=0$, we obtain an optimistic solution, one that allows you to get the maximum winnings. What size coefficient to choose depends on the type of decision - optimistic or pessimistic negotiator chooses. Perhaps it is the most acceptable factor $\gamma=0.5$, because this is a situation where the average solution is selected between pessimistic and optimistic. This gambling can be written by the so-called winnings matrix array and is called gambling. Zero-sum games form:

$$
\Gamma=\left\{\mathrm{S}_{1}, \mathrm{~S}_{2} ; \mathrm{A}\right\} \text {. }
$$

Applying it to the negotiating challenges it can be suggested that the first negotiators set of strategies (pure strategies) is $S_{1}=\left\{S_{11}, S_{12}, \ldots, S_{1 s}\right\}$, and set of pure strategies of second negotiator is $S_{2}=\left\{S_{21}, S_{22}, \ldots, S_{2 k}\right\}$. $S_{1}$ ir $S_{2}$. They are finite and known. Function of winnings is $A=$ $\left\|\mathrm{a}_{\mathrm{uz}}\right\|_{\mathrm{sxk}}$. Negotiators moves set is complete, it consists of s moves, which are numbered as $\mathrm{u}=1$, $2,3, \ldots, \mathrm{s}$. We accept the assumption that opponent's possible set of moves is finite and consists of $\mathrm{k}$ moves $\mathrm{z}=1,2,3, \ldots, \mathrm{k}$.

Gambling matrix is used to find the most advantageous strategy for negotiating issue. Every play has a finite solution in pure or mixed strategies and the net value of solution complies with the inequality: $\alpha \leq v \leq \beta$.

If $\alpha=\beta=\mathrm{v}$, then solution with clear strategies is a saddle point (only one optimal strategy for each player).

The number $\alpha$ is called the lowest slot value, $\beta$ - largest gambling value, $v$ is called the net value of gaming or gambling price.

By using game theory methods for specific tasks it is needed efficiency indicators of a pure value which must express relationship with optimum value and must be independent from matrix.

We shall use simple additive weighting method (SAW) of exponential expression using different degree of measure criteria values in cases of the best minimal and the best maximum values, when normalized values are limited in the range $[0,1]$ :

$$
\begin{gathered}
a_{u z}=\left(\frac{\min _{u} c_{u z}}{c_{u z}}\right)^{3}, \text { if } \min _{u} c_{u z} \text { advantageous, } \\
a_{u z}=\left(\frac{c_{u z}}{\max _{u} c_{u z}}\right)^{2}, \text { if } \max _{u} c_{u z} \text { advantageous. }
\end{gathered}
$$

The latter formula we will use for the normalization of negotiations indicators in order to facilitate the processing of the outcome of negotiations and to obtain comparative values. 
Keeping the initial data about the importance of indicators on negotiating issues, it is necessary to determine the significance of parameters characterizing the negotiating issues (Ginevičius et al. 2014; Ginevičius et al. 2008; Berth et al. 2000; Mandow Cruz 2003; Wibowo, Deng 2013; Azar 2014). Indicators significance will show how many times the usefulness rate of one or another negotiating issue is higher (lower) than another indicator's usefulness. Knowing significance of the negotiations issue parameters there can be determined each of their values in such a way (Ginevičius, Podvezko 2008a; Ginevičius, Podvezko 2008b; Ginevičius et al. 2008; Stewart et al. 2013; Ehtamo et al. 2001; Martin Ramos et al. 2010; Lourenzutti, Krohling 2014; Chang, Wu 2011; Azar 2014; Keršulienė 2008):

1. Elected the most significant indicator of negotiations issue $-\mathrm{a}_{\text {ger }}$;

2. For the best value of analysed issue is given 1 point value of significance $\left(a_{\text {ger }}=1\right)$;

3. It is determined by how many percent $\left(q_{v}\right)$ the values of remaining indicators $\left(b_{v}\right)$ are worse than the best $\left(\mathrm{a}_{\text {ger }}=1\right)$;

4. It is determined by how many percent $\left(\mathrm{q}_{\mathrm{v}}\right)$ the values of remaining indicators $\left(\mathrm{b}_{\mathrm{v}}\right)$ are worse than the best $\left(\mathrm{a}_{\mathrm{ger}}=1\right)$;

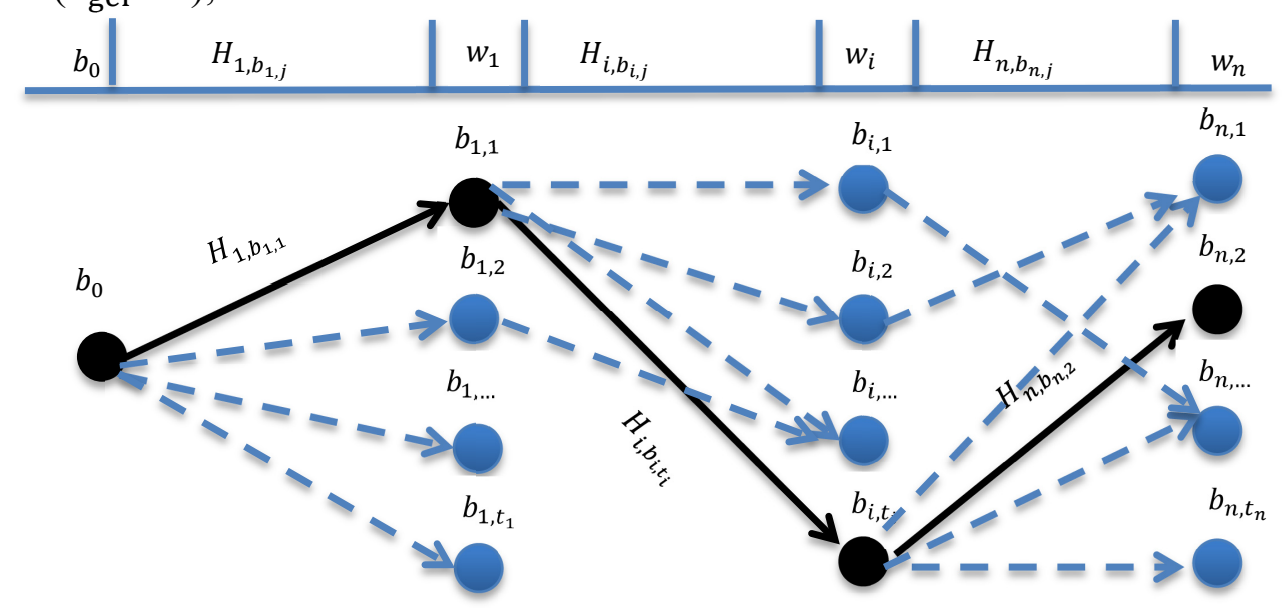

Fig. 1. Graph of negotiations (composed by the author)

5. It is determined by how many percent $\left(\mathrm{q}_{\mathrm{v}}\right)$ the values of remaining indicators $\left(\mathrm{b}_{\mathrm{v}}\right)$ are worse than the best $\left(\mathrm{a}_{\mathrm{ger}}=1\right)$;

6. For indicators values are granted the relative values $\left(\mathrm{a}_{\mathrm{v}}=1-\mathrm{q}_{\mathrm{v}} / 100\right)$;

7. The relative values of all indicators $\left(\mathrm{q}_{\mathrm{v}}\right)$ are converted in such a way that their sum would be equal to one:

$\sum_{\mathrm{v}=1}^{\mathrm{m}} \mathrm{q}_{\mathrm{v}}=1 ; \mathrm{v}=1,2, \ldots, \mathrm{m}$.

We use multiple criteria evaluation in case of using game theory methods when the issue of negotiations deals with more than one indicator. This estimation of few normalized indicators will be used in gaming matrix in order to find the winning of negotiations issue.

The negotiation process can be shown in the graph (Figure 1).

The peak $b_{0}$ marks the start of negotiations, peaks $b_{i j}$ marks the $j$-th alternative of the $i$-th issue, and the graph arc $\mathrm{H}_{\mathrm{i}, \mathrm{b}_{\mathrm{ij}}}$ indicates winning which we have after choosing the $\mathrm{j}$-th alternative in solving the $\mathrm{i}$-th issue. Below is given a global optimization task for a fixed number of negotiating issues, which are foreseen in negotiating agenda before negotiations.

Table 1 presents theoretical model of international business negotiation strategy based on estimation the bargaining power. In the model are made ratings of bargaining power for three subjects: the negotiations participant, his opponent, the competitor of negotiations participant. The bargaining power of these subjects is assessed according to their importance in the negotiations participant's strategy, which is based on the bargaining power estimation. These entities directly influence decision-making in preparing negotiating strategy.

In the model evaluation of bargaining power of all subjects of negotiations and preparing strategy of negotiations are carried out in this order: first is carried out non-linear normalization of 
the indicators of negotiation issues; multi-criteria evaluation of negotiations issues indicators; gaming matrix is used to find the most advantageous negotiating strategies on the issue; optimality rules are used to find the maximum win of the negotiations issues; optimization task is solved to find the maximum win for the negotiations; finally, the comparison of assessed bargaining powers is carried out and decision-making.

Created model for negotiating strategy development will be used for preparing international business negotiation strategies based on the bargaining power assessment. This negotiating strategy development model later will be used in solving complex issues and problems of negotiations. We will investigate whether model designed is effective for support of international business negotiations in case of wholesale.

\section{The Methodology of the Empirical Study Designed to Test Strategy Development Model Based on the Assessment of Bargaining Power in International Business Negotiations}

In this paper, empirical studies attempts to analyze negotiating strategy based on the assessment of bargaining power in a typical field of international business negotiation - in the case of wholesale trade. In order properly adjust and check the created model of business negotiation strategy based on evaluations of bargaining power in international negotiations. This study is necessary, because it can show the potential applicability of the model and check its basic settings. In the empirical study are used the following research methods: logical analysis, logical generation. comparison of findings and generalization techniques; mathematical and statistical methods of data analysis used in processing and analyzing empirical data obtained through studies of statistical analysis performed using SPSS (Statistical Package for the Social Sciences) software. Game theory methods (Xu et al. 2012; Pena et al. 2014; Cevikel et al. 2010; Panda et al. 2014; Zavadskas et al., 2004; Apynis March 2007; Žilinskas 2007) and multiple criteria evaluation are used to carry out an assessment of business entities bargaining power in international business negotiations, in order to choose effective strategic decisions in international business negotiations. This is done using MathLab software.

The study raised the following hypothesis:

H1: International business negotiation practice. There is a lack of dispositions and possibilities for a reasonable and adequate assessment of various business entities negotiating power, according to one of the circumstances of multiculturalism occurring in modern conditions of business internationalization and to the distance negotiating technology and e-business development opportunities.

$\mathrm{H} 2$ : international business negotiation strategies based on the assessment of bargaining power give effective results in negotiations compared to the negotiations, which are not based on the assessment of bargaining power.

The first (H1) and second (H2) hypotheses will attempt to prove with the help of analysis of preparing negotiating strategy based on the assessment of bargaining power in a typical field of international business negotiation - in the case of wholesale trade. Empirical research is oriented towards search of the basic parameters of model and justification of its application.

Following is given a diagram of empirical studies (Fig. 2). 


\section{Table 1. International business negotiation strategy and the preparation of the theoretical model based on bargaining power estimation (composed by the author)}

\begin{tabular}{|c|c|c|c|c|}
\hline & $\begin{array}{c}\text { Subjects interested in } \\
\text { negotiations }\end{array}$ & Negotiations participant & Negotiations opponent & $\begin{array}{c}\text { Competitor of negotiations } \\
\text { participant }\end{array}$ \\
\hline No. & $\begin{array}{l}\text { The order of application of the } \\
\text { algorithm formulas }\end{array}$ & \multicolumn{3}{|c|}{ Mathematical expressions of steps of the algorithm } \\
\hline 1. & $\begin{array}{l}\text { Is performed nonlinear Peldschus } \\
\text { normalization of negotiations } \\
\text { issue indicators. }\end{array}$ & \multicolumn{3}{|c|}{$\begin{array}{l}a_{u z}=\left(\frac{\min _{u} c_{u z}}{c_{u z}}\right)^{3} \text { if } \min _{u} c_{u} \text { z favorable, } \\
a_{u z}=\left(\frac{c_{u z}}{\max _{u} c_{u z}}\right)^{2} \text { if } \max _{u} c_{u z} \text { favorable. }\end{array}$} \\
\hline 2. & $\begin{array}{l}\text { Multiple criteria evaluation on } \\
\text { negotiation issues indicators. }\end{array}$ & \multicolumn{3}{|c|}{$\begin{array}{l}\text { 1. Election of the most significant indicator of negotiations issue }-\mathrm{a}_{\mathrm{ger}} \text {; } \\
\text { 2. For the best value of analysed issue is given } 1 \text { point value of significance }\left(\mathrm{a}_{\mathrm{ger}}=1\right) \text {; } \\
\text { 3. It is determined by how many percent }\left(\mathrm{q}_{\mathrm{v}}\right) \text { the values of remaining indicators }\left(\mathrm{b}_{\mathrm{v}}\right) \text { are } \\
\text { worse than the best }\left(\mathrm{a}_{\mathrm{ger}}=1\right) \text {; } \\
\text { 4. For indicators values are granted the relative values }\left(\mathrm{a}_{\mathrm{v}}=1-\mathrm{q}_{\mathrm{v}} / 100\right) \text {; } \\
\text { 5. The relative values of all indicators } \\
\left(\mathrm{q}_{\mathrm{v}}\right) \text { are converted in such a way that their sum is equal to one: } \\
\text { a. } \quad \sum_{\mathrm{v}=1}^{\mathrm{m}} \mathrm{q}_{\mathrm{v}}=1 ; \mathrm{v}=1,2, \ldots, \mathrm{m} \text {. }\end{array}$} \\
\hline 3. & $\begin{array}{l}\text { Gaming matrix is solved in order } \\
\text { to find the most advantageous } \\
\text { strategy for negotiating issue. }\end{array}$ & \multicolumn{3}{|c|}{$\begin{array}{l}\text { The form of zero-sum games: } \\
\qquad \Gamma=\left\{S_{1}, S_{2} ; A\right\} \text {. } \\
\text { Applying it to solve the negotiating issues you may suspect that a set of the first negotiators strategies } \\
\text { (pure strategies) is } S_{1}=\left\{S_{11}, S_{12}, \ldots, S_{1 s}\right\} \text {, and a set of the second negotiators pure strategies is } \\
S_{2}=\left\{S_{21}, S_{22}, \ldots, S_{2 k}\right\} . S_{1} \text { ir } S_{2} \text { are finite and known. Function of winnings is } A=\left\|a_{u z}\right\|_{s x k} \\
\text { A set of negotiators moves is finite and consists of s moves, which will be numbered } \mathrm{u}=1,2,3 \text {, } \\
\ldots, \text { s. } \\
\text { We accept the assumption that your opponent's set of possible moves is finite, which consists of } \mathrm{k} \\
\text { moves. These moves shall be numbered } \mathrm{z}=1,2,3, \ldots, \mathrm{k} \text {. } \\
\text { Every finite gambling has a solution in pure or mixed strategies and the net value reflects the } \\
\qquad \alpha \leq v \leq \beta \text {. } \\
\text { If } \alpha=\beta=\mathrm{v} \text {, then solution with clear strategies is a saddle point (only one optimal strategy for each } \\
\text { player). } \\
\text { The number } \alpha \text { is called the lowest slot value, } \beta \text { - largest gambling value, } v \text { is called the net value of } \\
\text { gaming or gambling price. }\end{array}$} \\
\hline 4. & $\begin{array}{l}\text { The optimality rules are usedin } \\
\text { order to find the maximum win of } \\
\text { the negotiations issue (as the } \\
\text { example is provided Hurwitz } \\
\text { rule). }\end{array}$ & \multicolumn{3}{|c|}{$\begin{array}{l}H_{u}=\max _{u}\left[\gamma \min _{z} a_{u z}+(1-\gamma) \max _{z} a_{u z}\right] \text { (The best maximal decision); } \\
H_{u}=\min _{u}\left[\gamma \max _{z} a_{u z}+(1-\gamma) \min _{z} a_{u z}\right] \text { (The best minimal decision); } \\
\quad \text { Where: } \\
\mathrm{H} \text { - the participants winning of negotiation issue according Hurwitz rule, } \\
\quad a_{u z}-\text { the winning, which participant could get if he will make the move uin case if his } \\
\text { opponent will make the move } \mathrm{z} \text {. } \\
\text { Negotiators moves alternatives set is complete and consists of } s \text { moves, which will be numbered } \mathrm{u}=1 \text {, } \\
2,3, \ldots, \mathrm{s} \text {. } \\
\text { We accept the assumption that opponent's possible set of moves is finite and consists of } k \text { moves } \mathrm{z}=1 \text {, } \\
2,3, \ldots, \mathrm{k} \text {. } \\
\gamma-\text { the hope parameter, } \gamma-\text { a factor that varies from } 0 \text { to } 1 \text {. }\end{array}$} \\
\hline 5. & $\begin{array}{l}\text { Optimization task is solved in } \\
\text { order to find the maximum } \\
\text { winnings of negotiations }\end{array}$ & \multicolumn{3}{|c|}{$\begin{array}{l}\text { Where: } \\
\mathrm{H} \text { - the participants winning of negotiation issue according Hurwitz rule, } \\
\mathrm{n}-\text { amount of negotiating issues (the peaks note the start and the end of negotiating issue). } \\
\text { Noted } \mathrm{b}_{0} \text { as the start of negotiations, the whole process of negotiations can be presented as } \\
\text { graph-tree (Fig. 1), where graph arc } \mathrm{H}_{\mathrm{i}, \mathrm{b}_{\mathrm{ij}}} \text { indicates the winnings, which can be achieved by selecting } \mathrm{j} \text { - } \\
\text { th alternative in solving the i-th issue } \\
\qquad \mathrm{k} \in \mathrm{w}_{1} \times \mathrm{w}_{2} \times \mathrm{w}_{3} \ldots \mathrm{w}_{\mathrm{n}} \text {. } \\
\text { After defining the priotity list of negotiation issues, let us note, that on each negotiating issue there } \\
\text { negotiations with a set of potential partners of negotiations. Let us assume that set of negotiator's } \\
\text { alternatives is finite and each issue consists from } t \text { alternatives. Alternatives of i-th issue will be noted } \\
\text { as } b_{i, j}, j=1,2,3, \ldots, t_{i} \text {. Then i-th issue set of all alternatives we shall note as } \\
w_{i}=\left\{b_{i, 1}, b_{i, 2}, \ldots, b_{i, t_{i}}\right\}, \text { o } w_{1} \times w_{2} \times w_{3} \ldots w_{n} \text { which is set of all possible nagatiations scenario, } \\
\text { when on each issue is selected one from possible alternatives, } \mathrm{n} \text { is amount of negotiations issues. }\end{array}$} \\
\hline 6. & $\begin{array}{l}\text { Comparison of bargaining powers } \\
\text { and decision making }\end{array}$ & Strategy of international busin & tiations based on estima & argaining powers. \\
\hline
\end{tabular}




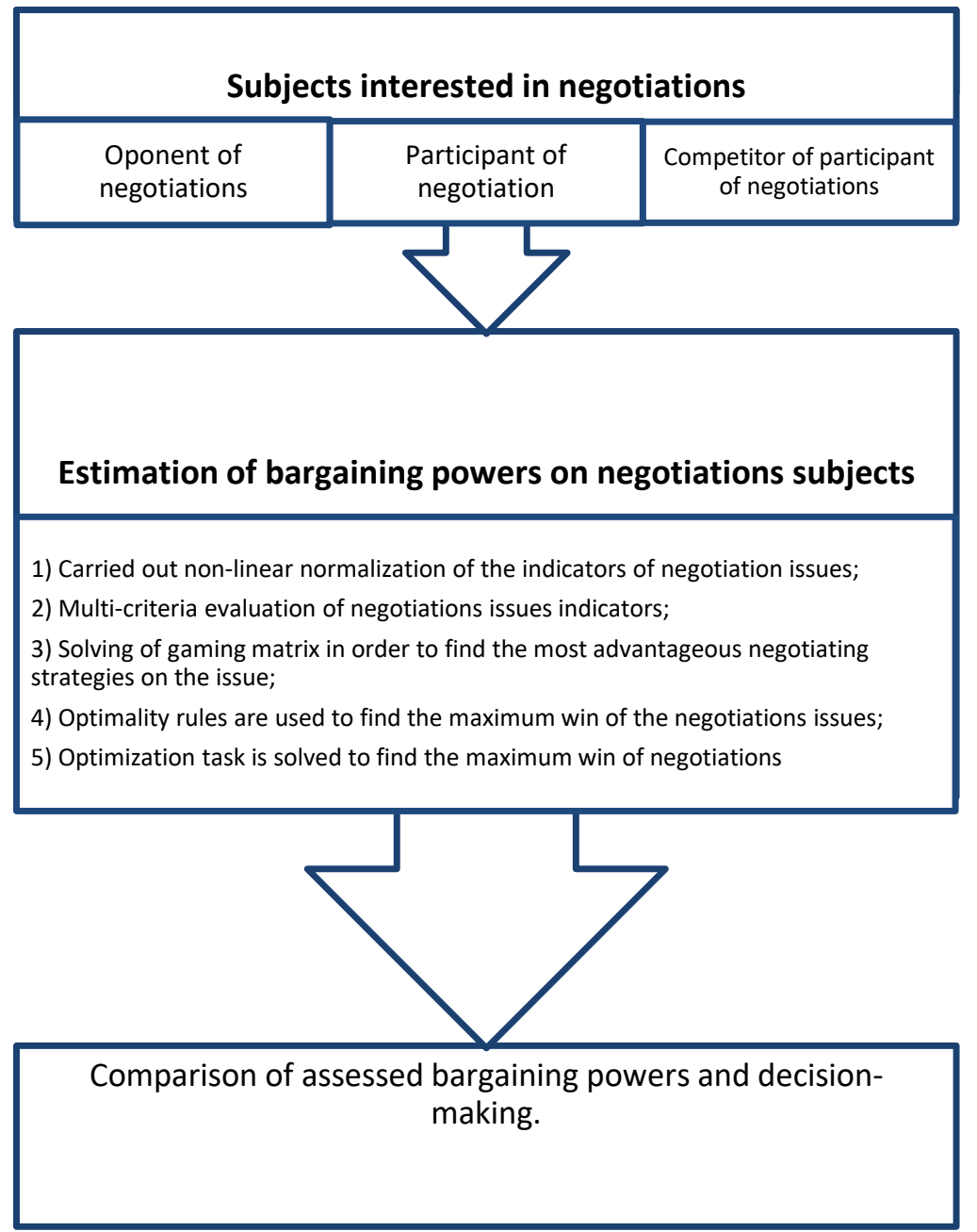

Fig. 2. Empirical Research Scheme (composed by the author)

The case of wholesale trade is the most common in international business negotiations. The research is carried out taking into account the specifics of this sphere. After checking the suitability of this model in typical case there could be considered further studies about its applicability in other areas. In this study, are used game theory methods, heuristic algorithm (Berth et al. 2000; Mandow Cruz 2003; Wibowo, Deng 2013; Azar 2014; Tamošiūnas 2011), multi-criteria evaluation.

For multi-criteria assessment of negotiations are invited the experts from the spheres of relevant negotiating concrete cases. There are analyzed subjects involved in the negotiations and their negotiating objects, who are representing a typical international business negotiation case. Specific details on the subjects and objects of negotiations are confidential in order not to disclose their trade secrets, so presentation of research data is limited. However, the presented data enable to reflect investigation process and its results.

For empirical verification of the model it is appropriate to rely on game theory methods, because it allows to analyze the interaction of objects having their own goals. This is particularly important in international business negotiations where representatives of different cultures are meeting, and this creates a lot of uncertainties. In order to develop the international business negotiation strategy based on the assessment of bargaining power, it is appropriate to use game theory methods that help to create a model for preparation of effective strategies. Game theory is described as a set of methods for handling conflict situations. Its purpose is to prepare recommendations in accepting rational solutions for the participants of conflict (Bivainis, 2011). To use of game theory methods always is available when it is possible to foresee options of negotiators activities, analyzing one version of each negotiating party (the player) (Keršulienè, 2008). Of course, game theory can't fully define the decisions in all cases of negotiations but practice has proven that game theory methods are the perfect tool helping to make reasonable and appropriate strategic decisions. In many situations of business negotiations negotiators often must make decisions under uncertainty. Of 
course, in the assessment of bargaining power we tried to reduce this information deficit, but this was not possible to achieve fully due to the large number of variables. Therefore, there are invoked various rules for calculating the optimal strategies.

\section{Characteristic of Typical Case for Strategy Development Based on the Assessment of Bargaining Power in International Business Negotiations}

We will continue to study characteristic of a typical case for strategy development based on the assessment of bargaining power in international business negotiations - wholesale trade case. We will review the importance of this activity in the EU and Lithuania. The analysis has been prepared on the basis of data from Eurostat (in 2015), the Ministry of Economy of Lithuania (in 2015) Department of Statistics of Lithuania (in 2015 and in 2014) and the Bank of Lithuania (in 2015).

Wholesale trade. According to the Lithuanian Department of Statistics (2015) in 2014 year Lithuanian exports of goods amounted to 24.4 billion EUR, import - 26.5 billion EUR. Lithuania mainly exported to Russia, Latvia, Poland and Germany. Mostly goods of Lithuanian origin were exported to the EU (almost 70 per cent of the total exports). The main partners of Lithuanian exports were Germany, Latvia, the Netherlands and Poland (Lithuanian Department of Statistics, 2015). Most of the goods were imported to Lithuania from Russia, Germany, Poland and Latvia. Goods imported from the EU countries increased by 7.2 percent in value and amounted 63.8 percent from the total Lithuanian import. Russian imports decreased by 14.8 percent and amounted 27.6 percent of the total import of Lithuania (Lithuanian Department of Statistics, 2015). Due to unfavorable geopolitical changes, a decline in export prices, the devalued currencies of Russia and other Commonwealth of Independent States not only in Lithuania, but also in the European Union (EU (28)) declined exports of goods, which Lithuania traders are re-exporting and due their competitive opportunities. Slow growth of exports of goods and services can be partially linked to the geopolitical situation in the eastern part of Europe and the slowly recovering demand in Western markets. The sustained tension between Russia and Ukraine, it seems, has worsened and the overall investment climate for companies particularly related to Eastern European markets. In the last quarter of 2014 year export was inhibited by some factors (Lithuanian Ministry of Economy, 2015): complicated geopolitical situation in the region (the Russian embargo of the EU food industry and agricultural production, as well as other Russian-Ukrainian conflict escalation aspects), falling export prices for products and quite slope Western markets demand (Lithuanian Ministry of Economy, 2015). Re-exports during 2014 year fourth quarter grew by 4.6 percent (throughout 2014 - 8.7 percent). Despite trade restrictions and the worsening economic situation in Russia and on the markets belonging to the Lithuanian trade, logistics and transport company found enough business opportunities for East-West (EU-Russia) supply chain (Lithuanian Ministry of Economy, 2015). As we can see, the latter activities in EU and Lithuania are significant. Therefore, in further research will be carried out of strategy development based on the assessment of bargaining power in international business negotiations in wholesale trade.

\section{Wholesale Strategy Development Based on the Assessment of Bargaining Power in International Business Negotiations}

This study will examine model of strategy development based on the assessment of bargaining power in international business negotiations - case of the wholesale trade.

It will allow to check out the adequacy of created negotiating strategy development model for business negotiation support based on the assessment of bargaining power, there will be carried out assessment of bargaining power through negotiation stakeholders, according which will be prepared strategy. The study will include 4 international business entities. Next are described the participants and the context of negotiations.

Situation and its context. Retail chain renovates its stores in Lithuania, Latvia and Estonia. He is looking for a supplier of external cladding panels. The supply agreement would be concluded for a fixed period and substances. Lithuania has already renovated a number of shops with these matters. 
Suppliers must have their own warehouses in Eastern Europe according the request, the plates should be delivered within a few days.

Business entities who are interested in negotiations:

Participant No. 1 - competitor for negotiation participants No. 3 and No. 4. This business entity is the supplier of facade panels with extensive operating experience. This participant sells other construction materials for negotiating opponent (the participant No. 2). However, until now he has not sold facade panels for negotiating opponent because the latter buy facade panels from the participant No. 3.

Participant No. 2 - the contracting business entity - negotiating opponent. This is a retail chain that searches good quality, but cheap facade decoration. This negotiation opponent is looking for companies which can supply materials reliably without interruptions.

Participant No. 3 - entity who gets negotiation support. This participant supplies facade panels for 5 years. Participant No. 2 carried out many construction projects from the supplied materials, so switching can cause inconvenience, as there may be different shades of boards and other parameters.

Participant No. 4 - is a competitor for negotiations participants No.1 and No. 3. This competitor supplies facade panels from Asia. However, this business entity had several cases where products had quality problems and did not meet the standards. That was publicized in press and held pre-trial investigations.

The winnings of negotiations will be assessed in relation to the business entity which purchases products. The negotiating with other business entities will take part in these international negotiations ( 1 formula). The criteria by which proposals will be evaluated in accordance to other business entities: duration (months), price (in euros), the probability of delays to pay (per cent). The results of probability on delivery time, price and delay to pay will be minimized ( 5 formula). For the evaluation importance of negotiating issue criteria are invoked experts from negotiating team (10 wholesale trade sector experts - project managers, managers, brokers and clients). Concordance rate is calculated to determine the compatibility of the expert opinions (16-19 formula). Then is given a normalized decision matrix (5-6 formula) in Wald, Savage and Niehaus, Bernoulli-Laplace, Bayes-Laplace, Hodges and Lehmann. Accordingly, under the applicable rules of optimization there were adopted the same source data for all rules: the hope factor of 0.5 ; and the probability of the event 0.25 . Each entity provides 4 offers of alternatives. However, the accuracy of the negotiating results is determined by the possible uncertainty of information. Therefore, to reduce this negative impact on the lack of information, in order to reduce uncertainties there have been used credit information on business entities. In Annex 1 are presented evaluation data of initial negotiation proposals. There are selected the optimality criteria and consequently are chosen the best rates. The experts from negotiating team are employed to assess the relevance of negotiations issues criterion. Next there are given results of the expert's assessment on indicators significance (Tables 2 and 3 ).accordance with the relevant criteria and calculated the total value of alternatives.

Table 2. The matrix of the expert's evaluation

\begin{tabular}{|c|c|c|c|c|}
\hline \multicolumn{5}{|c|}{ Estimation of criteria weight by negotiation expert group } \\
\hline \multirow[b]{2}{*}{ Experts } & \multicolumn{3}{|c|}{ Criteria } & \multirow[b]{2}{*}{ Sum } \\
\hline & 1 & 2 & 3 & \\
\hline 1 & 0,6 & 0,3 & 0,1 & 1 \\
\hline 2 & 0,5 & 0,2 & 0,3 & 1 \\
\hline 3 & 0,6 & 0,3 & 0,1 & 1 \\
\hline 4 & 0,6 & 0,3 & 0,1 & 1 \\
\hline 5 & 0,6 & 0,3 & 0,1 & 1 \\
\hline 6 & 0,5 & 0,3 & 0,2 & 1 \\
\hline 7 & 0,7 & 0,2 & 0,1 & 1 \\
\hline 8 & 0,7 & 0,2 & 0,1 & 1 \\
\hline 9 & 0,6 & 0,3 & 0,1 & 1 \\
\hline 10 & 0,6 & 0,3 & 0,1 & 1 \\
\hline Sum & 6 & 2,7 & 1,3 & 10 \\
\hline
\end{tabular}


Table 3. The matrix of the expert's evaluation ranking

\begin{tabular}{|c|c|c|c|c|}
\hline \multicolumn{5}{|c|}{ Matrix of the experts evaluation ranking } \\
\hline & \multicolumn{3}{|c|}{ Criteria } & \multirow[b]{2}{*}{ Sum } \\
\hline Experts & 1 & 2 & 3 & \\
\hline 1 & 1 & 2 & 3 & 6 \\
\hline 2 & 1 & 3 & 2 & 6 \\
\hline 3 & 1 & 2 & 3 & 6 \\
\hline 4 & 1 & 2 & 3 & 6 \\
\hline 5 & 1 & 2 & 3 & 6 \\
\hline 6 & 1 & 2 & 3 & 6 \\
\hline 7 & 1 & 2 & 3 & 6 \\
\hline 8 & 1 & 2 & 3 & 6 \\
\hline 9 & 1 & 2 & 3 & 6 \\
\hline 10 & 1 & 2 & 3 & 6 \\
\hline Sum & 10 & 21 & 29 & 60 \\
\hline $\begin{array}{l}\text { Ranking sum } \\
\text { average }\end{array}$ & 20 & 20 & 20 & \\
\hline Deviation & 100 & 1 & 81 & 182 \\
\hline $\begin{array}{l}\text { Concordation } \\
\text { coefficient W }\end{array}$ & & 91 & & \\
\hline
\end{tabular}

In another step we shall compare gaming performance by applying different rules of optimization (4 and 7-15 formula). There was a choice of following rules (7-15 formula): Hurwitz, Wald, Savage and Niehaus, Bernoulli-Laplace, Bayes-Laplace, Hodges and Lehmann. Accordingly, under the applicable rules of optimization there were adopted the same source data for all rules: the hope factor of 0.5 ; and the probability of the event 0.25 . Each entity provides 4 offers of alternatives. However, the accuracy of the negotiating results is determined by the possible uncertainty of information. Therefore, to reduce this negative impact on the lack of information, in order to reduce uncertainties there have been used credit information on business entities. In Annex 1 are presented evaluation data of initial negotiation proposals. There are selected the optimality criteria and consequently are chosen the best rates. The experts from negotiating team are employed to assess the relevance of negotiations issues criterion. Further are given rules of optimization:

\section{Wald rule}

$\mathrm{S}_{1}^{*}=\left\{\mathrm{S}_{1 \mathrm{i}} \mid \mathrm{S}_{1 \mathrm{i}} \in \mathrm{S}_{1} \cap\left\{\mathrm{S}_{1 \mathrm{i} 0} \mathrm{a}_{\mathrm{i} 0 \mathrm{j} 0} \max _{\mathrm{i}} \min _{\mathrm{j}} \mathrm{a}_{\mathrm{ij}}\right\}\right\}$,

Hurwicz rule

$$
A_{j}=\max _{i}\left((1-\lambda) \min _{j} a_{i j}+\lambda \max _{j} a_{i j}\right)
$$

$A_{j}=\min _{i}\left((1-\lambda) \max _{j} a_{i j}+\lambda \min _{j} a_{i j}\right)$,

$\mathrm{S}_{1}^{*}=\left\{\mathrm{S}_{1 \mathrm{i}} \mid \mathrm{S}_{1 \mathrm{i}} \in \mathrm{S}_{\mathrm{i}} \cap\left\{\mathrm{S}_{1 \mathrm{i} 0} \mid \mathrm{h}_{\mathrm{i} 0}=\max _{\mathrm{i}} \mathrm{h}_{\mathrm{i}} ; \mathrm{h}_{\mathrm{i}}=\max _{\mathrm{i}}(1-\lambda) \min _{\mathrm{j}} \mathrm{a}_{\mathrm{ij}}+\lambda \max _{\mathrm{j}} \mathrm{a}_{\mathrm{ij}} ; 0 \leq \lambda \leq 1\right\}\right\}$.

Savage and Niehaus rule

$\mathrm{S}_{1}^{*}=\left\{\mathrm{S}_{1 \mathrm{i}} \mid \mathrm{S}_{1 \mathrm{i}} \in \mathrm{S}_{1} \cap\left\{\mathrm{S}_{1 \mathrm{io}} \mid \mathrm{r}_{\mathrm{i} 0 \mathrm{j0}}=\min _{\mathrm{i}} \max _{\mathrm{j}} \mathrm{r}_{\mathrm{ij}}\right\}\right\}$.

here $\mathrm{r}=\overline{1 \mathrm{~m}} ; \mathrm{s}=\overline{1, \mathrm{n}}$.

Bernoulli-Laplace rule

$\mathrm{S}_{1}^{*}=\left\{\mathrm{S}_{1 \mathrm{i}} / \mathrm{S}_{1 \mathrm{i}} \in \mathrm{S}_{1} \cap \max _{\mathrm{i}}\left(1 / \mathrm{n} \sum_{\mathrm{i}=1}^{\mathrm{n}} \mathrm{a}_{\mathrm{ij}}\right)\right\}$.

Bayes-Laplace rule

$\mathrm{S}_{1}^{*}=\left\{\mathrm{S}_{1 \mathrm{i}} / \mathrm{S}_{1 \mathrm{i}} \in \mathrm{S}_{\mathrm{i}} \cap \max _{\mathrm{i}}\left(\sum_{\mathrm{j}=1}^{\mathrm{n}} \mathrm{q}_{\mathrm{j}} \mathrm{a}_{\mathrm{ij}}\right) \cap \sum_{\mathrm{j}=1}^{\mathrm{n}} \mathrm{q}_{\mathrm{j}}=1\right\}$.

Hodges-Lehmann rule

$S_{1}^{*}=\left\{\begin{array}{c}\frac{S_{1 i}}{S_{1 i}} \in S_{i} \cap \max _{i}\left[\lambda \sum_{j=1}^{n} a_{j} a_{i j}=(1-\lambda) \min _{j} a_{i j}\right] \\ \cap 0 \leq \lambda \leq 1\end{array}\right.$

Werner rule

$S_{1}^{*}=\left\{S_{1 i} \mid S_{1 i} \in S_{i} \cap\left\{S_{1 i 0} \mid a_{i 0}=\max _{i \in M_{\varepsilon}} a_{i j} ; M_{\varepsilon i}=\left\{i \mid \max _{i} a_{i j} \min _{j} a_{i j}-a_{i j} \leq \varepsilon\right\} ; \max _{j} a_{i j} \geq \max _{j} a_{i 0 j}\right\}\right.$. $\varepsilon-$ the extent of the risk.

\section{Concordance coefficient}

Concordance coefficient $\mathrm{W}$ is calculated by the following formula (Ginevičius et al., 2008; Sėrikovienè, 2013; Maskeliūnaitè, 2012): 
$\mathrm{W}=\frac{12 \mathrm{~S}}{\mathrm{r}^{2} \mathrm{~m}\left(\mathrm{~m}^{2}-1\right)}$

Here $r$ - the number of experts, $m$ - the evaluates the indicators number.

The value $\mathrm{S}$ is calculated as follows:

Calculating assessments made by experts $e_{i k}$ each indicator rank-sum $e_{i}$ by the following formula (Ginevičius et al., 2008; Sèrikovienè, 2013; Maskeliūnaitè, 2012):

$\mathrm{e}_{\mathrm{i}}=\sum_{\mathrm{k}=1}^{\mathrm{r}} \mathrm{e}_{\mathrm{ik}}$,

The total number of grades on average $\overline{\mathrm{e}}$ by the following formula (Ginevičius et al., 2008):

$\overline{\mathrm{e}}=\frac{\sum_{\mathrm{i}=1}^{\mathrm{m}} \mathrm{e}_{\mathrm{i}}}{\mathrm{m}}$

Value S, t.y. rank-sum $e_{i}$ deviations from the general average $\bar{e}$ the sum of the squares counted by the following formula (Ginevičius et al., 2008):

$$
\mathrm{S}=\sum_{\mathrm{i}=1}^{\mathrm{m}}\left(\mathrm{e}_{\mathrm{i}}-\overline{\mathrm{e}}\right)^{2} \text {, }
$$

In the next step is presented normalized decision matrix (5-6 formula), in which are adjusted criteria for significance. In 4 - 6 tables are provided gaming matrix normalized according importance of the criteria (Formula 4). Figure 3 compares the results of gaming observed with various optimization rules. The diagram (Fig. 3) provides summary of the results of winnings on the negotiation support (2.8 - 16.2 and 1 formulas), according to optimization rules. There is displayed information which negotiators proposal was with the biggest winnings according to different optimization rules, as well as the cumulative winnings for all issues. In Figure 3 are given support of winnings of wholesale trade business negotiations in each question under different optimization rules: Hurwitz, Wald, Savage and Niehaus, Bernoulli-Laplace, Bayes-Laplace, Hodges and Lehmann. Optimization rules enable us to simulate various situations in the negotiations, to see the maximum, average and minimum winnings. The choice of principles and rules must carry out negotiators with high qualifications and experience in the fields concerned.

Table 4. Normalized decision-making matrix (negotiations between the Participant No. 1 and Participant No. 2)

\begin{tabular}{|c|c|c|c|c|}
\hline \multicolumn{5}{|c|}{ Normalized decision-making matrix } \\
\hline \multirow[b]{2}{*}{ Alternatives } & \multicolumn{3}{|c|}{ Criteria } & \multirow[b]{2}{*}{$\begin{array}{c}\text { Sum by } \\
\text { significance }\end{array}$} \\
\hline & Delivery term, months. & Price, EUR & $\begin{array}{c}\text { Possibility of pay delay, } \\
\text { percent }\end{array}$ & \\
\hline A1R1 & 1,000 & 0,579 & 1,000 & 0,886 \\
\hline A1R2 & 1,000 & 0,687 & 1,000 & 0,915 \\
\hline A2R1 & 1,000 & 1,000 & 1,000 & 1,000 \\
\hline A2R2 & 1,000 & 0,422 & 1,000 & 0,844 \\
\hline W11 & $\mathbf{A 1}$ & $\mathbf{A 2}$ & & \\
\hline R1 & 0,886 & 1,000 & & \\
\hline $\mathbf{R 2}$ & 0,915 & 0,844 & & \\
\hline
\end{tabular}

Table 5. Normalized decision-making matrix (negotiations between the Participant No. 3 and Participant No. 2)

\begin{tabular}{|c|c|c|c|c|}
\hline \multicolumn{5}{|c|}{ Normalized decision-making matrix } \\
\hline \multirow{2}{*}{ Alternatives } & \multicolumn{3}{|c|}{ Criteria } & \\
\cline { 2 - 5 } & Delivery term, months & Price, EUR & Possibility of pay delay, percent & Sum by significance \\
\hline A1R1 & 1,000 & 0,715 & 1,000 & 0,923 \\
\hline A1R2 & 1,000 & 0,835 & 1,000 & 0,956 \\
\hline A2R1 & 1,000 & 1,000 & 1,000 & 1,000 \\
\hline A2R2 & 1,000 & 0,766 & 1,000 & 0,937 \\
\hline & & & & \\
\hline W12 & $\mathbf{A 1}$ & $\mathbf{A 2}$ & & \\
\hline R1 & 0,923 & 1,000 & & \\
\hline R2 & 0,956 & 0,937 & & \\
\hline
\end{tabular}


Table 6. Normalized decision-making matrix (negotiations between the Participant No. 4 and Participant No. 2)

\begin{tabular}{|c|c|c|c|c|}
\hline \multicolumn{5}{|c|}{ Normalized decision-making matrix } \\
\hline \multirow{3}{*}{ Alternatives } & \multicolumn{4}{|c|}{ Criteria } \\
\cline { 2 - 5 } & $\begin{array}{c}\text { Delivery term, } \\
\text { months. }\end{array}$ & $\begin{array}{c}\text { Price, } \\
\text { EUR }\end{array}$ & $\begin{array}{c}\text { Possibility of pay delay, } \\
\text { percent }\end{array}$ & Sum by significance \\
\hline A1R1 & 1,000 & 0,463 & 1,000 & 0,855 \\
\hline A1R2 & 1,000 & 0,670 & 1,000 & 0,911 \\
\hline A2R1 & 1,000 & 1,000 & 1,000 & 1,000 \\
\hline A2R2 & 1,000 & 0,367 & 1,000 & 0,829 \\
\hline & & & & \\
\hline W13 & $\mathbf{A 1}$ & $\mathbf{A 2}$ & & \\
\hline R1 & 0,855 & 1,000 & & \\
\hline R2 & 0,911 & 0,829 & & \\
\hline
\end{tabular}

In order to determine which option is the best it is necessary to assess specifics, goals and conditions of each task, so there are offered such cases for use: in the examination of multiple negotiations and making a lot of decisions it is advisable to apply Bayes (Bayes-Laplace) and Hurwitz principles. If negotiations are single, it is better to apply the minimax and Savage-Niehaus principles. If under certain conditions is unacceptable even minimal risk it should be based on the principle of Wald. If it is possible partial risk, then it is applicable Hodges and Lehman rule to calculate the optimal strategies. In considering the negotiation strategies support for wholesale trade business negotiations, it can be noted that the strategic principles of the negotiations can vary in each question. Results chart shows that optimistic - the highest win provides Savage and Niehaus optimization rule, the lowest winnings - Wald rule. Accordingly Hurwitz, Bernoulli-Laplace and Laplace-Bayes rules were showed very similar results, and Hodges and Lehman gave slightly higher winnings, than the lowest winnings having demonstrated the Wald rule. Figure 4 are given sum for all optimization rules winnings results.

The calculations according to the created model on evaluation of the negotiating powers set that the greatest negotiating power has participant No. 3 (the other participants had less negotiating powers to negotiate with the negotiator No. 2). While participant No. 3 did not use these study results on support of negotiations, but he have reached an agreement with the participant No.2. This confirms that it is an effective negotiation support to the development of wholesale trade.

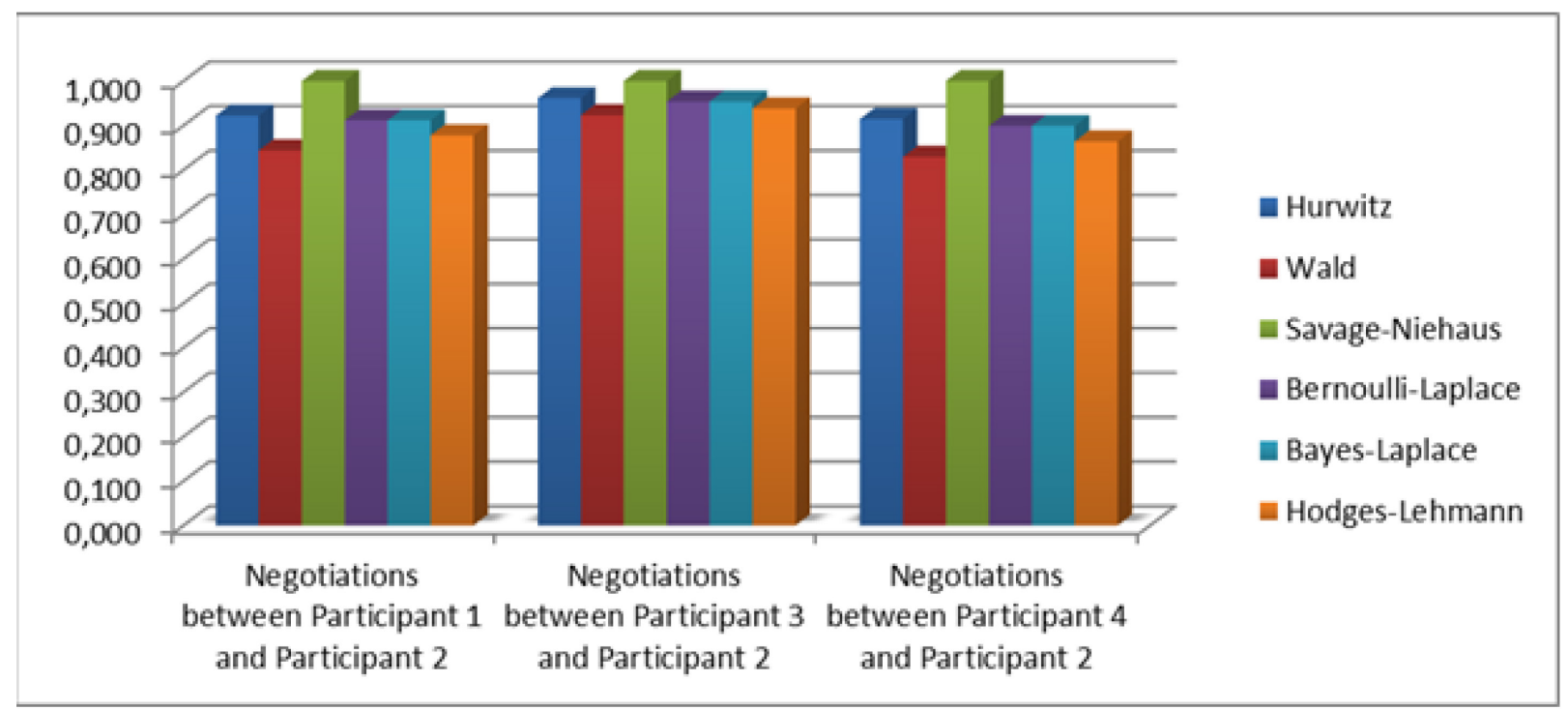

Fig. 3. Participants of the negotiations winnings distribution in wholesale trade case, using different optimization rules (normalized values) 


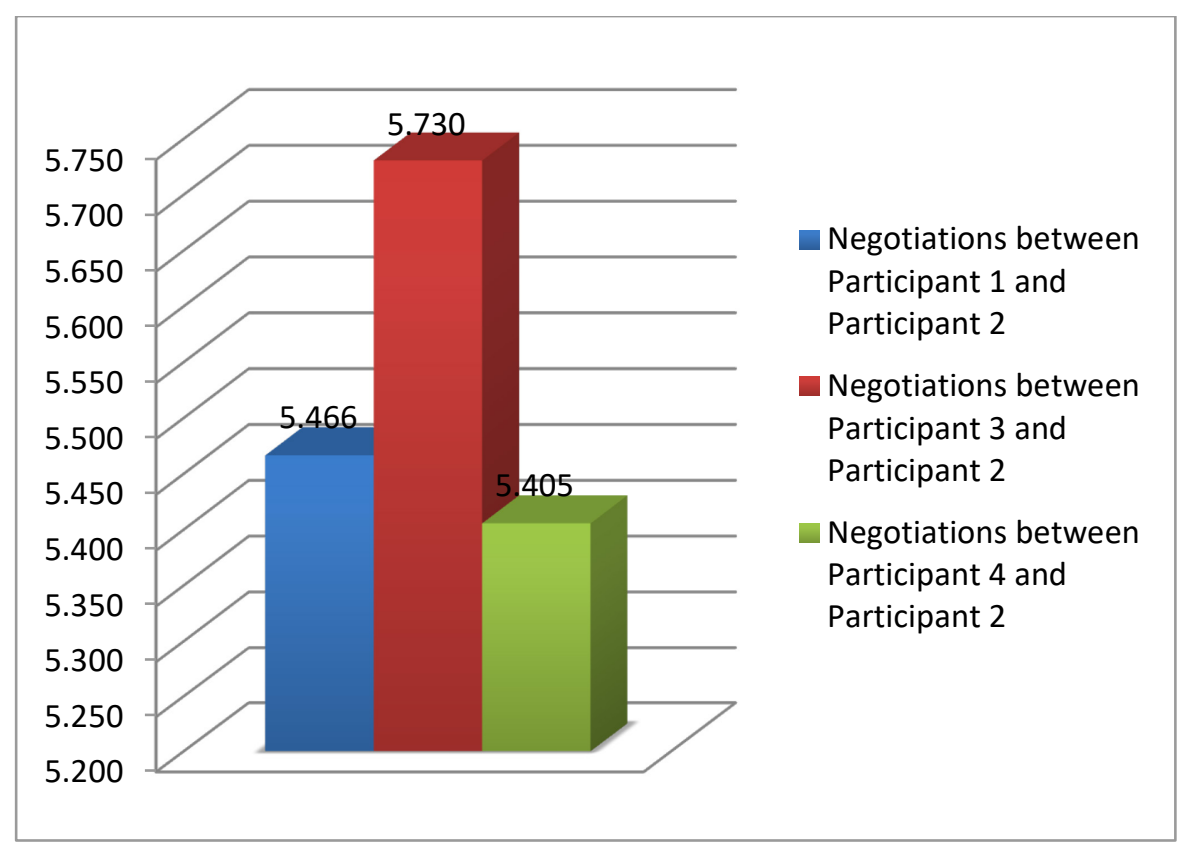

Fig. 4. International business negotiation participants bargaining power assessment sum results in wholesale trade case (normalized values)

\section{Conclusions}

It was established that the negotiating strategy model, based on the assessment of bargaining power, allowed to take more effective strategic decisions than without using this model. Therefore, we can conclude that the results confirm the first and second hypotheses. Prospects of utilization the developed model of international business negotiations: negotiation support tool, information uncertainty reduction measure, independent engine of the negotiation process, management of large quantities information, improving communication conditions.

In this paper is developed and described model, based on assessments of bargaining power on negotiating strategy development and implementation. Is described empirical research methodology for preparation and control application of model, based on assessments of bargaining power on negotiating strategy development and implementation. It is appropriate to adapt this model and to check it in typical international business of other areas of negotiations: services, transport and logistics services, attraction of new investment, e-commerce cases.

From the research results it can be stated that the developed international business negotiation strategy planning model can be used for wholesale trade negotiations: both as a standalone tool or as a means partly demanding intervention of the negotiator. As well created negotiation strategy model can be used to support the negotiations through various databases. Results of the investigation can be used to create business negotiation strategies in international business, with regard to globalization, internationalization and cooperation processes characterized by multiculturalism. The complex decision support model of international business negotiations allows adequately to evaluate the bargaining power of participants of negotiations and business stakeholders, take into account comprehensive real factors, affecting the outcome of negotiations, different countries and cultural cooperation specifics, to optimize international business negotiation strategy development and implementation processes, to use effective negotiating powers of international business development under modern conditions. Recently for optimization management tasks are applied heuristic optimization technique, relying on a variety of solution search paradigms, which are often developed by analogy with nature, applying artificial intelligence techniques and so on. Heuristic algorithms in negotiations are purposeful due to the nature of the negotiations - knowledge of negotiating power is going in the negotiation process itself, thereby reducing the uncertainty that hampers negotiating situations by using the rules for calculating the optimal strategy (Wald, Werner, Hurwitz et al.). To deal with these tasks are developed a number of 
heuristic algorithms which calculates optimum possible to get result over time. Heuristic algorithms are used for optimization problems, and they help to achieve high quality. Negotiation is based on the gradual knowledge of negotiating power of the other side of negotiations, so with every issue you can use other tactics. So, heuristic algorithms can help to manage effectively the negotiation process. Selection of principles and rules must be carried out by specialists of high qualifications and experience, consultants, negotiators in the fields concerned, in order to determine which option is the best, taking into account the specifics of each task, goals and conditions.

\section{References}

[1] Apynis, A. 2007. Lošimų teorija, Vilnius: Vilniaus universiteto leidykla, ISBN 978-9986-19980-9, 2007, $107 \mathrm{p}$.

[2] Azar, O. H. 2014. The default heuristic in strategic decision making: When is it optimal to choose the default without investing in information search?, Journal of Business Research, Volume 67, Issue 8, August 2014, Pages 1744-1748, ISSN 0148-2963, http://dx.doi.org/10.1016/j.jbusres.2014.02.021.

[3] Bivainis, J. 2011. Vadyba studentams: mokomoji knyga. Vilniaus Gedimino technikos universitetas.Vilnius : Technika, 2011. ISBN: 9789955289333

[4] Cevikel, A. C.; Ahlatçıoğlu, M. 2010. Solutions for fuzzy matrix games, Computers \& Mathematics with Applications, Volume 60, Issue 3, August 2010, Pages 399-410, ISSN 08981221, http://dx.doi.org/10.1016/j.camwa.2010.04.020.

[5] Chang, Y. H.; Wu, T. T. 2011. Dynamic multi-criteria evaluation of co-evolution strategies for solving stock trading problems, Applied Mathematics and Computation, Volume 218, Issue 8, 15 December 2011, Pages 4075-4089, ISSN 0096-3003, http://dx.doi.org/10.1016/j.amc.2011.09.032.4

[6] Ehtamo, H.; Kettunen, E.; Hämäläinen, R. P. 2001. Searching for joint gains in multi-party negotiations, European Journal of Operational Research, Volume 130, Issue 1, 1 April 2001, Pages 54-69, ISSN 0377-2217, http://dx.doi.org/10.1016/S0377-22170000019-9.

[7] Eurostat, 2015. Nacionalinès sąskaitos ir BVP. [žiūrèta: 2015 m. rugpjūtis 12 d.,] Interaktyvi nuoroda: http://ec.europa.eu/eurostat/statisticsexplained/index.php?title=National_accounts_and_GDP/lt\&oldid=146923

[8] Ginevičius, R. 2008. Normalization of quantities of various dimensions, Journal of Business Economics and Management, 9:1, 79-86

[9] Ginevičius, R.; Podvezko, V. 2008a. Daugiakriterinio vertinimo būdų suderinamumas. Verslas: Teorija ir praktika $9(1) .73-80$ psl.

[10] Ginevičius, R.; Podvezko, V. 2008b. Daugiakriterinio vertinimo taikymo galimybès kiekybiniam socialinių reiškinių vertinimui. Verslas: Teorija ir praktika 9 (2). 81-87 psl.

[11] Ginevičius, R.; Podvezko, V.; Raslanas, S. 2008. Evaluating the alternative solutions of wall insulation by multicriteria methods, Journal of Civil Engineering and Management, 14:4, 217226

[12] Ginevičius, R.; Suhajda, K.; Petraškevičius, V.; Šimkūnaitė, J. 2014. Lithuanian Experience of Quantitative Evaluation of Socioeconomic Systems Position by Multicriteria Methods, Procedia - Social and Behavioral Sciences, Volume 110, 24 January 2014, Pages 952-960, ISSN 1877-0428, http://dx.doi.org/10.1016/j.sbspro.2013.12.941. 
[13]Keršulienè, V. 2008. Užsakovo ir rangovo racionalaus ginčų sprendimo būdo nustatymas lošimų teorijos metodais. Daktaro disertacija. Technologijos mokslai, statybos inžinerija 02T. 128 psl. ISBN 978-9955-28-277-8

[14]Lietuvos bankas, 2015. Lietuvos ekonomikos raida ir perspektyvos.

[15]Lietuvos Respublikos ūkio ministerija, 2015. Lietuvos ekonomikos apžvalga.

[16]Lietuvos statistikos departamentas, 2014. Informacinès technologijos Lietuvoje. Vilnius. 98 psl. ISSN 2029-3615

[17]Lourenzutti, R.; Krohling, R. A. 2014. The Hellinger distance in Multicriteria Decision Making: An illustration to the TOPSIS and TODIM methods, Expert Systems with Applications, Volume 41, Issue 9, July 2014, Pages 4414-4421, ISSN 0957-4174, http://dx.doi.org/10.1016/j.eswa.2014.01.015.

[18]Lova, A.; Maroto, C.; Tormos, P. 2000. A multicriteria heuristic method to improve resource allocation in multiproject scheduling, European Journal of Operational Research, Volume 127, Issue 2, 1 December 2000, Pages 408-424, ISSN 0377-2217, http://dx.doi.org/10.1016/S037722179900490-7.

[19]Mandow, L.; Pérez de la Cruz, J.L. 2003. Multicriteria heuristic search, European Journal of Operational Research, Volume 150, Issue 2, 16 October 2003, Pages 253-280, ISSN 03772217, http://dx.doi.org/10.1016/S0377-22170200517-9.

[20]Martín Ramos, J. M.; López García, D.; Gómez-Bravo, F.; Blanco Morón, A. 2010. Application of multicriteria decision-making techniques to manoeuvre planning in nonholonomic robots, Expert Systems with Applications, Volume 37, Issue 5, May 2010, Pages 3962-3976, ISSN 0957-4174, http://dx.doi.org/10.1016/j.eswa.2009.11.019.

[21]Panda, A.; Das, C. B. 2014. Multi-choice linear programming for matrix game, Applied Mathematics and Computation, Volume 237, 15 June 2014, Pages 411-418, ISSN 0096-3003, http://dx.doi.org/10.1016/j.amc.2014.03.017.

[22]Peña, J.; Lehmann, L.; Nöldeke, G. 2014. Gains from switching and evolutionary stability in multi-player matrix games, Journal of Theoretical Biology, Volume 346, 7 April 2014, Pages 23-33, ISSN 0022-5193, http://dx.doi.org/10.1016/j.jtbi.2013.12.016.

[23] Stewart, T. J.; French, S.; Rios, J. 2013. Integrating multicriteria decision analysis and scenario planning-Review and extension, Omega, Volume 41, Issue 4, August 2013, Pages 679-688, ISSN 0305-0483 http://dx.doi.org/10.1016/j.omega.2012.09.003.

[24] Tamošiūnas, L. 2011. Euristinių paieškos algoritmų tyrimas ir taikymas atviro kodo geografinèse informacinèse sistemose. Magistro darbas. Kauno technologijos universitetas. 41 psl.

[25] Wibowo, S.; Deng, H. 2013. Consensus-based decision support for multicriteria group decision making, Computers \& Industrial Engineering, Volume 66, Issue 4, December 2013, Pages 625633, ISSN 0360-8352, http://dx.doi.org/10.1016/j.cie.2013.09.015.

[26] Xu, Y.; Liu, J.; Zhong, X.; Chen, S. 2012. Lattice-valued matrix game with mixed strategies for intelligent decision support, Knowledge-Based Systems, Volume 32, August 2012, Pages 5664, ISSN 0950-7051, http://dx.doi.org/10.1016/j.knosys.2011.08.019.

[27]Zavadskas, E. K.; Peldschus F., Ustinovičius, L., Turskis, Z. 2004. Lošimų teorija statybos technologijoje ir vadyboje. Monografija. Vilnius: Technika, 2004. 196 p.

[28]Žilinskas, K. 2007. Matematinis programavimas I dalis. Tiesinis programavimas. Šiaulių universitetas. 304 psl. ISBN 978-9986-38-838-8 